\title{
Enzymes produced by agro-industrial co-products enhance digestible values for Nile tilapia (Oreochromis niloticus): A significant animal feeding alternative.
}

\author{
Paula K. Novelli ${ }^{\mathrm{a}, *}$, Margarida M. Barros ${ }^{\mathrm{b}}$, Luiz Edivaldo Pezzato ${ }^{\mathrm{b}}$, Eric Portilho de Araujo ${ }^{\mathrm{b}}$, \\ Renan de Mattos Botelho ${ }^{\mathrm{b}}$, Luciana F. Fleuri ${ }^{\mathrm{a}}$ \\ a Departamento de Química e Bioquímica, IBB, UNESP, Univ. Estadual Paulista, CP 510, 18618-970 Botucatu, SP, Brazil \\ b AquaNutri, FMVZ, UNESP, Univ. Estadual Paulista, CP 560, 18618-970 Botucatu, SP, Brazil
}

\section{A R T I C L E I N F O}

\section{Keywords:}

Phytase

Protease

Solid State Fermentation (SSF)

Animal nutrition

Phytate-protein

Mineral complexing

\begin{abstract}
A B S T R A C T
The use of enzymes in animal feed is common practice nowadays and its utilization has shown good results for improving the efficiency of nutrient utilization. In this sense, the goal of this work was to add low cost fungal phytases and proteases, with promising biological characteristics, produced by Solid State Fermentation using agro-industrial co-products to improve nutritional availability of plant based diets for Nile tilapia. Considering the enzymes chosen for the digestibility trail, Aspergillus niger produced acid phytases, as A. oryzae, produced proteases withoptimum $\mathrm{pH}$ over 8 . The enzymes were stable at high temperatures $\left(90{ }^{\circ} \mathrm{C}\right.$ for phytase and $50{ }^{\circ} \mathrm{C}$ for protease) and showed very distinct behavior when different substrates were tested. Subsequently, the upscale production of $A$. niger phytase and $A$. oryzae protease with $7000 \mathrm{U} \mathrm{g}^{-1}$ and $2500 \mathrm{U} \mathrm{g}^{-1}$, respectively, were applied as additive in a plant protein based fish diet. They increased protein, mineral, energy and lipids

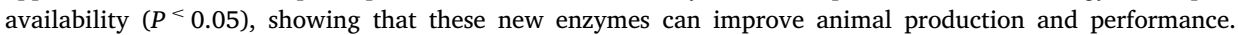
Additionally, these low cost enzymes are an alternative as additives to improve soybean meal digestibility in fish plant based diets.
\end{abstract}

\section{Introduction}

The intensification of fish production requires improved production technology and low cost and low pollution feeding systems. Due to high cost and limited availability of animal protein sources; its replacement by plant protein has been encouraged. The utilization of soybean meal as feed ingredient has some advantages like availability, amino acid profile and environmental sustainability (Hardy, 2010; Hassaan et al., 2015). However, plant protein ingredients contain anti-nutritional factors that reduce the availability of nutrients and minerals, increasing waste output (Hardy, 2010). Phytic acid is the major anti-nutritional factor, which is the phosphorous storage compound in most plant protein sources (Cheryan, 1980). Phytate (IP6) is a salt of myo-inositol $1,2,3,4,5,6$-hexakis dihydrogen phosphate, which is present in several portions in plant seeds. Most phosphorous bound to phytate (PIP6) is excreted by fish into the water due to its low availability, this can make phosphorous less available for fish utilization on its metabolism. In addition, this molecule binds to metal ions and also to cationic groups in proteins and amino acids. It has been demonstrated that IP6 can inhibit pepsin and other proteases activity in vitro by the formation of binary protein-IP6 complexes (Morales et al., 2011).

Phytases (E.C. 3.1.3.8 and E.C. 3.1.3.26) are a special class of phosphatases that catalyze the sequential hydrolysis of IP6 to less phosphorylated myo-inositol derivatives and inorganic phosphate. One of the main commercial phytases used in animal nutrition is produced from Escherichia coli and has two $\mathrm{pH}$ optima at 2.5 and 4.5 (Elkhalil et al., 2007). However, some latest studies demonstrate the utilization of new fungal phytases in fish diets with promising results (Liebert and Portz, 2005; Dalsgaard et al., 2009). It has been demonstrated that the addition of phytase to plant ingredients used in fish nutrition improves phosphorous availability and also prevents binding of IP6 to protein, this resulting in increased nutrient utilization (Storebakken et al., 1998). It has been also suggested that a number of factors such as $\mathrm{pH}$, nature of the protein source and the presence of digestive proteases may determine the effect of phytase on protein and minerals bioavailability within fish digestive tract (Morales et al., 2011). Details of the specific effects of such factors on the action of phytase efficacy have not been elucidated yet and more research is needed to obtain a better insight

\footnotetext{
* Corresponding author at: Chemical Engineering Department, Federal University of São Carlos, Rod. Washington Luiz, Km 235, 13565-905 São Carlos, SP, Brazil.

E-mail address: paula@novellisouza.com.br (P.K. Novelli).
} 
Table 1

Formulation $\left(\mathrm{g} \mathrm{kg}^{-1}\right)$ and proximate composition (\% dry matter) of the experimental diets with two plant protein based ingredients and enzyme addition.

\begin{tabular}{|c|c|c|c|c|c|c|c|c|c|}
\hline Diets & Reference & $\mathrm{SB}^{\mathrm{a}}$ & $\mathrm{CG}^{\mathrm{a}}$ & $\mathrm{SBF}^{\mathrm{a}}$ & $\mathrm{SBP}^{\mathrm{a}}$ & $\mathrm{SBFP}^{\mathrm{a}}$ & $\mathrm{CGF}^{\mathrm{a}}$ & $\mathrm{CGP}^{\mathrm{a}}$ & $\mathrm{CGFP}^{\mathrm{a}}$ \\
\hline \multicolumn{10}{|l|}{ Ingredients } \\
\hline Soybean & 561.61 & 692.95 & 392.95 & 692.95 & 692.95 & 692.95 & 392.95 & 392.95 & 392.95 \\
\hline Corn & 367.69 & 257.27 & 257.27 & 257.02 & 256.27 & 256.02 & 257.02 & 256.27 & 256.02 \\
\hline Corn gluten & & & 300.00 & & & & 300.00 & 300.00 & 300.00 \\
\hline Soybean oil & 14.20 & 9.94 & 9.94 & 9.94 & 9.94 & 9.94 & 9.94 & 9.94 & 9.94 \\
\hline L-Lysine & 1.35 & 0.94 & 0.94 & 0.94 & 0.94 & 0.94 & 0.94 & 0.94 & 0.94 \\
\hline DL-Methionine & 3.49 & 2.44 & 2.44 & 2.44 & 2.44 & 2.44 & 2.44 & 2.44 & 2.44 \\
\hline Threonine & 3.08 & 2.16 & 2.16 & 2.16 & 2.16 & 2.16 & 2.16 & 2.16 & 2.16 \\
\hline Dicalcium phosphate & 39.58 & 27.71 & 27.71 & 27.71 & 27.71 & 27.71 & 27.71 & 27.71 & 27.71 \\
\hline Premix $^{\mathrm{b}}$ & 5.00 & 3.50 & 3.50 & 3.50 & 3.50 & 3.50 & 3.50 & 3.50 & 3.50 \\
\hline Vit $C^{\mathrm{c}}$ & 0.50 & 0.35 & 0.35 & 0.35 & 0.35 & 0.35 & 0.35 & 0.35 & 0.35 \\
\hline $\mathrm{BHT}^{\mathrm{d}}$ & 0.20 & 0.14 & 0.14 & 0.14 & 0.14 & 0.14 & 0.14 & 0.14 & 0.14 \\
\hline $\mathrm{NaCl}$ & 1.00 & 0.70 & 0.70 & 0.70 & 0.70 & 0.70 & 0.70 & 0.70 & 0.70 \\
\hline Coline & 1.30 & 0.91 & 0.91 & 0.91 & 0.91 & 0.91 & 0.91 & 0.91 & 0.91 \\
\hline $\mathrm{Cr}_{2} \mathrm{O}_{3}{ }^{\mathrm{e}}$ & 1.00 & 1.00 & 1.00 & 1.00 & 1.00 & 1.00 & 1.00 & 1.00 & 1.00 \\
\hline Phytase & & & & 0.25 & & 0.25 & 0.25 & & 0.25 \\
\hline Protease & & & & & 1.00 & 1.00 & & 1.00 & 1.00 \\
\hline \multicolumn{10}{|l|}{ Analyzed composition } \\
\hline Dry matter & 93.0 & 94.2 & 94.3 & 92.5 & 93.6 & 93.4 & 93.0 & 93.6 & 92.9 \\
\hline Protein & 34.8 & 40.6 & 46.0 & 40.4 & 40.4 & 38.9 & 45.4 & 45.2 & 45.4 \\
\hline Lipids & 3.7 & 3.2 & 2.2 & 3.2 & 3.5 & 2.8 & 1.3 & 2.2 & 1.8 \\
\hline Energy $\left(\mathrm{kJ} \mathrm{g}^{-1}\right)$ & 18.8 & 19.2 & 20.7 & 19.0 & 18.9 & 19.0 & 20.7 & 20.5 & 20.5 \\
\hline Ash & 6.4 & 5.8 & 5.1 & 5.4 & 5.8 & 6.6 & 5.7 & 5.7 & 5.5 \\
\hline $\mathrm{Cr}_{2} \mathrm{O}_{3}{ }^{\mathrm{e}}$ & 0.1 & 0.1 & 0.1 & 0.1 & 0.1 & 0.1 & 0.1 & 0.1 & 0.1 \\
\hline Phosphorous & 1.2 & 1.0 & 0.9 & 1.0 & 1.0 & 1.0 & 1.0 & 1.0 & 1.0 \\
\hline Magnesium & 0.45 & 0.41 & 0.29 & 0.38 & 0.37 & 0.44 & 0.27 & 0.29 & 0.31 \\
\hline Calcium & 1.25 & 0.98 & 0.87 & 0.94 & 1.07 & 1.08 & 0.82 & 0.98 & 0.85 \\
\hline Manganese & 0.008 & 0.004 & 0.006 & 0.005 & 0.008 & 0.008 & 0.006 & 0.008 & 0.006 \\
\hline
\end{tabular}

${ }^{a}$ SB: Soybean meal test diet without enzyme; CG: Corn gluten test diet without enzyme; SBF: Soybean meal diet with phytase; SBP: Soybean meal diet with protease; SBFP: Soybean meal diet with phytase and protease; CGF: corn gluten diet with phytase; CGP: Corn gluten diet with protease; CGFP: Corn gluten diet with phytase and protease.

${ }^{\mathrm{b}}$ Vitamin and mineral supplement (levels per $\mathrm{kg}$ of product): vitamin $\mathrm{A}=1200,000 \mathrm{IU}$; vitamin $\mathrm{D} 3=200,000 \mathrm{IU}$; vitamin $\mathrm{E}=12,000 \mathrm{mg}$; vitamin $\mathrm{K} 3=2400 \mathrm{mg}$; vitamin

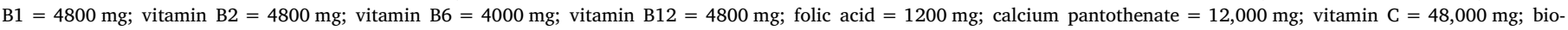
tin = $48 \mathrm{mg}$; choline =65,000 mg; nicotinic acid = 24,000 mg; Mn = $4.000 \mathrm{mg} ; \mathrm{Zn}=6.000 \mathrm{mg} ; \mathrm{I}=20 \mathrm{mg} ; \mathrm{Co}=2 \mathrm{mg} ; \mathrm{Cu}=4 \mathrm{mg}$ e Se $=20 \mathrm{mg}$.

c Vitamin C Rovimix@ Stay-35, DMS Nutritional Products, Switzerland.

d Butyl-hydroxytoluene.

e Chromium oxyde.

into the mechanisms underlying phytase-protein interactions and subsequent availability of proteins and amino acids after digestion in fish. Moreover, the right phytase, regarding especially $\mathrm{pH}$ and temperature, used as nutritional additive can have different effects in nutrient digestibility.

Proteases (EC 3.4.23.18) hydrolyze peptide bonds, so protein becomes more available for the animal. These enzymes constitute an important group of enzymes commercially produced with different industrial applications and they are being used as animal feed additive recently. Nowadays, proteases constitute $>25 \%$ of biomolecules produced for industrial usage (Uyar and Baysal, 2004). Protein based food with several anti-nutritional factors and low nutritional availability are common in the animal feed industry. High levels of proteases inhibitors are found, mainly in soybean meal, which is one of the most important protein ingredients in animal fed. Studies with vegetable ingredients and enzyme addition in diets for animals showed promising results (Denstadli et al., 2011; Morales et al., 2011). Additionally, proteases can also help with reduction of environmental pollution as they increase nutrient availability and reduce losses to the environment.

The aim of this study was to determine the effect of supplemental low-cost homemade fungal phytase and protease on protein, energy and mineral availability by juvenile Nile-tilapia fed plant based protein diets.

\section{Materials and methods}

\subsection{Enzyme production}

The enzymes were obtained by solid fermentation using two different substrates provided by the Department of Animal Breeding and
Nutrition, University of São Paulo State: 1) wheat middling and 2) soybean meal; and fungal samples from lyophilized strains of Aspergillus niger (INCQS 40018) and Aspergillus oryzae (INCQS 40068) from Osvaldo Cruz Institute (FIOCRUZ), according Novelli et al. (2016). The crude extract enzyme activities were determined as described below.

The scale up of the process was done increasing the number of Erlenmeyer flasks and, at the same time, using flasks with double the size maintaining the proportion of substrate and sterilized water.

\subsection{Enzyme activity}

The phytase activity was determined using $p$-nitrophenyl phosphate as substrate at $\mathrm{pH} 5.0$ and $37{ }^{\circ} \mathrm{C}$. The phytase activity unit was the quantity of enzyme necessary to release one $\mu \mathrm{mol}$ of $p$-nitrophenol per reaction minute at $410 \mathrm{~nm}$. The control sample was measured with denaturized crude enzyme extract (Stockmann et al., 2003).

The protease activity was measured using azocasein as substrate, with modifications at $\mathrm{pH} 7.0$ and $37{ }^{\circ} \mathrm{C}$ (Charney and Tomarelli, 1947). The protease activity unit was defined as the quantity of enzyme necessary to increase 0.1 of absorbance at $428 \mathrm{~nm}$ in the assay conditions.

\subsection{Biochemical characterization}

For biochemical characterization, the optimal activity and stability of enzymes produced at different $\mathrm{pH}$ and temperature were tested.

\subsubsection{Effect of temperature on activity and stability}

The optimum temperature was determined as described for each enzyme activity (pH 5.0 to phytase and $\mathrm{pH} 7.0$ to protease) at different temperatures, as follows: $20,30,40,50,60,70,80$, and $90^{\circ} \mathrm{C}$ (Novelli 
et al., 2016).

The temperature stability was determined by incubating the crude enzyme extract at different temperatures for $1 \mathrm{~h}$, followed by determining the residual activity as described in the section above for enzymes activity.

\subsubsection{Effect of $p H$ on activity and stability}

Optimum $\mathrm{pH}$ was determined as described for each enzyme activity $\left(37^{\circ} \mathrm{C}\right.$ ) using buffer solutions at different $\mathrm{pH}$ values as follows: $0.1 \mathrm{M}$ acetate buffer $\mathrm{pH} 4.0$ and 5.0; $0.1 \mathrm{M}$ sodium phosphate buffer $\mathrm{pH} 6.0$ and 7.0; and $0.1 \mathrm{M}$ borax-boric acid buffer $\mathrm{pH} 8.0$ and 9.0 (Novelli et al., 2016).

The $\mathrm{pH}$ stability was determined by incubating the crude enzyme extract in buffer solutions at different $\mathrm{pH}$ values at $30{ }^{\circ} \mathrm{C}$ for $24 \mathrm{~h}$, followed by determining the residual activity as described in the section on protease activity.

\subsection{Diets}

Two diets were prepared with the test ingredients (soybean meal and corn gluten) added to a reference diet formulated as fish nutritional requirements (NRC, 2011) in a proportion of $30 \%(\mathrm{~m} / \mathrm{m})$, as proposed by Pezzato et al. (2004). Table 1 shows the calculated formulation and analysis of the experimental diets.

The diets were mixed with water ( $20 \%$ of dry weight) and extruded (5.0 mm pellet) at approximately $120^{\circ} \mathrm{C}$ in a single-screw laboratory extruder $\left(20 \mathrm{~kg} \mathrm{~h}^{-1}\right.$ of the feed; Esteec ${ }^{\circledR}$, Ribeirão Preto, SP, Brazil). The pellets were air dried overnight, enzymes were sprayed over the diets and the soybean oil was added at the end of the process. Then, it was stored at $4{ }^{\circ} \mathrm{C}$ until further use. The diets were added with $0.1 \%$ of chromic oxide $\left(\mathrm{Cr}_{2} \mathrm{O}_{3}\right)$ as an inert marker to determine nutrient availability.

Phytase from Aspergillus niger produced by Solid State Fermentation (SSF) at the Bioprocess Laboratory, Institute of Biosciences São Paulo State University was added to the diet in a ratio of $2000 \mathrm{U} \mathrm{kg}^{-1}$, as recommended by Portz and Liebert (2004) and, for protease produced by SSF with Aspegillus oryzae, $1500 \mathrm{U} \mathrm{kg}^{-1}$ was added, as recommended by Mahmoud et al. (2014). The determination of phytase activity in the experimental diets was performed using $p$-nitrophenyl phosphate as substrate, aliquot of $1000 \mu \mathrm{L}$ of $5 \mathrm{mmol} \mathrm{L}^{-1} p$-nitrophenyl phosphate were added to $500 \mu \mathrm{L}$ of acetate buffer $\mathrm{pH} 5.0\left(0.1 \mathrm{~mol} \mathrm{~L}^{-1}\right)$ and $100 \mathrm{mg}$ of the experimental diet. The system was incubated for $10 \mathrm{~min}$ at $37^{\circ} \mathrm{C}$. The reaction was stopped with $2 \mathrm{~mL}$ of sodium hydroxide $\left(0.1 \mathrm{~mol} \mathrm{~L}^{-1}\right)$. The protease activity was determined using azocasein as substrate. The reaction media was $0.5 \mathrm{~mL}$ of azocasein $0.5 \%(\mathrm{~m} / \mathrm{v})$ and $0.5 \mathrm{~mL}$ of diet solution $1: 5(\mathrm{~m} / \mathrm{v})$ in borax-boric acid buffer pH $9.0\left(0.1 \mathrm{~mol} \mathrm{~L}^{-1}\right)$, they were incubated for $40 \mathrm{~min}$ at $37^{\circ} \mathrm{C}$. The reaction was stopped with $0.5 \mathrm{~mL}$ TCA $10 \%(\mathrm{~m} / \mathrm{v})$ and centrifuged at $6000 \mathrm{rpm}$ for $15 \mathrm{~min}$ at $15{ }^{\circ} \mathrm{C} ; 1 \mathrm{~mL}$ of potassium hydroxide $\left(5 \mathrm{~mol} \cdot \mathrm{L}^{-1}\right.$ ) was added to $1 \mathrm{~mL}$ of the supernatant.

\subsection{Culture conditions, fish and feeding}

The experiment was evaluated by the Ethic Commission for Animal Utilization of the Veterinary and Animal Science College, University of São Paulo State "Julio de Mesquita Filho" under protocol number 20/ 2013-CEU and was implemented at AquaNutri, FMVZ, São Paulo State University - UNESP, Botucatu, SP, Brazil.

The apparent availability coefficient was determined according to Pezzato et al. (2004). Nine $250 \mathrm{~L}$ tanks were used for the feeding procedure, and five conical $300 \mathrm{~L}$ tanks were used to collect faeces via a settlement column. Both systems were connected to a biological filter and an electronic thermostat $\left(27.0 \pm 0.5^{\circ} \mathrm{C}\right.$. $)$. The water was circulated at $6.59 \mathrm{~L} \mathrm{~min}^{-1}$ through the aquaria. Groups of ten Nile tilapia/ aquarium $(150 \pm 5.0 \mathrm{~g})$ were used in the trail and diets were randomly assigned to each tank. Fish were fed seven days prior to the beginning of the faecal collection (acclimatization period). Fish were hand fed until apparent satiation from 8:00 am to 5:00 pm. At 6:00 pm, the cages were transferred to the collecting faeces aquaria. For this collection the first five groups of fish were transferred to collecting faeces aquaria and on the consecutive day the remaining four groups were transferred and faeces collected. This procedure was carried out until representative volume of faeces for each replication of chemical analysis was collected. The acclimatization and faecal collection process (round) were repeated three times to obtain triplicate measurements per treatment (test diets). Faeces were dried at $55^{\circ} \mathrm{C}$, ground and stored at $-20.0{ }^{\circ} \mathrm{C}$ until chemical analysis.

Chemical analysis of feedstuffs, diets and faeces were determined according AOAC (1995) protocols. Chromium oxide content of diets and faeces were determined according Bremer-Neto et al. (2005) and gross energy content was determined in an adiabatic calorimetric bomb (Parr Instrument Company, Moline-IL, EUA). Calcium, magnesium, manganese and phosphorous were mineralized with nitro-perchloric acid solution for further analyses. Phosphorous was determined by phospho-vanado-molybdate colorimetric method according Moraes et al. (2009); calcium, magnesium and manganese were determined using a SHIMADZU AA-6800 atomic absorption spectrometer equipped with a background absorption correction with a deuterium lamp and self-reverse (SR) system.

\subsection{Apparent digestibility coefficients $(A D C)$ calculation}

Below Eq. (1) was used to assess the apparent digestibility coefficients (ADC, \%) of dry matter protein, energy lipid and availability of phosphorous, calcium, manganese and magnesium of the experimental diets (Cho et al., 1982), as:

$\mathrm{ADC}=100-\left[100\left[\% \mathrm{Cr}_{2} \mathrm{O}_{3} \mathrm{r} / \mathrm{Cr}_{2} \mathrm{O}_{3} \mathrm{f}\right] \times[\% \mathrm{Nf} / \% \mathrm{Nr}]\right]$

where:

$\mathrm{ADC}=$ Apparent digestibility coefficient (\%);

$\% \mathrm{Cr}_{2} \mathrm{O}_{3} \mathrm{r}=$ diet chromium oxide III percentage;

$\% \mathrm{Cr}_{2} \mathrm{O}_{3} \mathrm{f}=$ faeces chromium oxide III percentage;

$\% \mathrm{Nf}=$ crude energy or percentage of dry matter, protein, lipids or minerals in the faeces;

$\% \mathrm{Nr}=$ crude energy or percentage of dry matter, protein, lipids or minerals in the diet.

The ADC of the experimental diets was used to calculate the apparent digestibility coefficient of dry matter, energy, protein and minerals availability of the test ingredients when enzymes were added according to Bureau et al. (1999) as follows (Eq. (2)):

$$
\begin{aligned}
\mathrm{ADC}_{\text {test ingredient }}= & \mathrm{ADC}_{\text {test diet }}+\left(\mathrm{ADC}_{\text {test diet }}-\mathrm{ADC}_{\text {ref diet }}\right) \\
& \times\left(\left(0.7 \times \mathrm{N}_{\text {ref diet }}\right) /\left(0.3 \times \mathrm{N}_{\text {test ingredient }}\right)\right)
\end{aligned}
$$

\subsection{Experimental design}

Nine compound diets were evaluated, eight containing the two plant test ingredients (soybean meal and corn gluten) and the addition or not of the supplemental enzymes (phytase, protease, both and no enzyme), and one reference practical diet, with three replicates for each combination. The digestibility was determined indirectly using $0.1 \%(\mathrm{~m} / \mathrm{m})$ of chromium oxide III as an inert marker. Analysis of variance test by SAS statistics was used and, when there was difference between averages, it was applied the Duncan test with 5\% significance.

\section{Results and discussion}

Aspergillus oryzae show no satisfactory performance when fermented in soybean bran. A. niger produced acid phytases in both substrates, as for $A$. oryzae, optimum $\mathrm{pH}$ was basic; optimum temperature was $37^{\circ} \mathrm{C}$ for $A$. niger and $30^{\circ} \mathrm{C}$ for A. oryzae (Fig. 1). Phytase produced by A. niger 

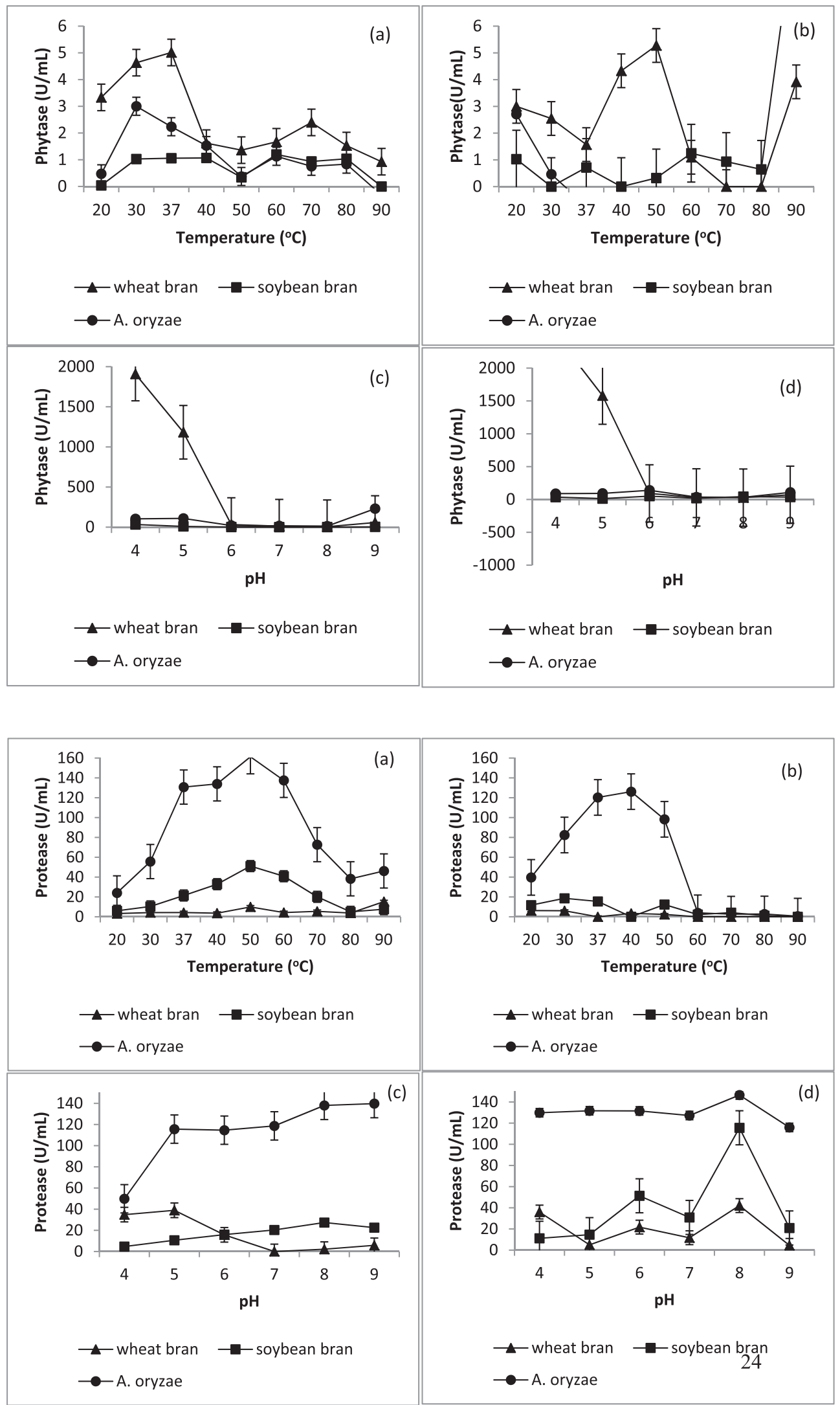

Fig. 1. Influence of temperature (a - optimum, and $\mathrm{b}$ - stability) and $\mathrm{pH}$ (c - optimim, and d stability) on phytase activity produced by solid fermentation with Aspegillus niger 40018 using wheat bran (- $\boldsymbol{-}$-) and soybean bran (- - ) as substrates and Aspergillus oryzae using wheat bran as substrate (-๑-).
Fig. 2. Influence of temperature (a - optimum, and $\mathrm{b}$ - stability) and $\mathrm{pH}$ (c - optimim, and $\mathrm{d}$ stability) on protease activity produced by solid fermentation with Aspegillus niger 40018 using wheat bran (- $\mathbf{-}$-) and soybean bran (- - -) as substrates and Aspergillus oryzae using wheat bran as substrate (-๑-). with both substrates showed different behavior for temperature stability at $50{ }^{\circ} \mathrm{C}$ and $90^{\circ} \mathrm{C}$ and $60{ }^{\circ} \mathrm{C}$ and $90{ }^{\circ} \mathrm{C}$, for fermentation in wheat bran and soybean bran, respectively (Fig. 1b). Besides this characteristic present isoforms of the enzyme, it also demonstrates the enzyme capacity to support high temperatures, that is essential in some industrial processes. Protease from A. niger showed very distinct behavior when different substrates were tested. Moreover, proteases from $A$. oryzae were stable at all pHs and produced higher yields (Fig. 2). 
Table 2

Apparent digestibility coefficients (ADC) of dry matter, protein, energy, lipids of plant ingredients, soybean meal and corn gluten, with fungal enzymes addition.

\begin{tabular}{|c|c|c|c|c|c|c|c|c|}
\hline \multirow[t]{2}{*}{ Treatment } & \multicolumn{4}{|c|}{ Soybean meal } & \multicolumn{4}{|l|}{ Corn gluten } \\
\hline & No enzyme & Phytase & Protease & Phytase + protease & No enzyme & Phytase & Protease & Phytase + protease \\
\hline Dry matter & $72.62 \mathrm{c}$ & $93.48 \mathrm{ab}$ & $94.39 \mathrm{ab}$ & $92.37 \mathrm{ab}$ & $94.43 \mathrm{ab}$ & $80.22 \mathrm{bc}$ & $84.57 \mathrm{abc}$ & $97.92 \mathrm{a}$ \\
\hline Protein & $93.92 \mathrm{bcd}$ & $98.47 \mathrm{a}$ & $97.36 \mathrm{ab}$ & $97.51 \mathrm{ab}$ & 95.17 abc & $91.47 \mathrm{~d}$ & $91.96 \mathrm{~cd}$ & $96.43 \mathrm{ab}$ \\
\hline Energy & $78.39 \mathrm{~b}$ & $94.87 \mathrm{a}$ & 94.87 a & $93.33 \mathrm{a}$ & $95.60 \mathrm{a}$ & $85.75 \mathrm{ab}$ & $88.52 \mathrm{ab}$ & $96.97 \mathrm{a}$ \\
\hline Lipid & $95.53 \mathrm{ab}$ & $104.83 \mathrm{a}$ & $105.02 \mathrm{a}$ & $110.83 \mathrm{a}$ & $77.23 \mathrm{bc}$ & $33.61 \mathrm{e}$ & $64.73 \mathrm{~cd}$ & $54.81 \mathrm{~d}$ \\
\hline
\end{tabular}

Values with different letters within a row indicate significant difference $(P<0.05)$.

In this study, we aimed to investigate the enzyme production and the nutritional availability of two types of plant protein based diets with and without enzymes addition for Nile tilapia. To this end, we tested eight diets including two protein sources, soybean meal and corn gluten, and the addition or not of phytase, protease and both enzymes. The addition of enzymes significantly affected nutrients digestibility when soybean meal was used as plant protein test ingredient; as for corn gluten, when compared to soybean meal with enzyme utilization, showed no difference.

There were significant differences in the apparent digestibility coefficient (ADC) of dry matter, protein, energy and lipids when phytase was added to soybean meal as plant based ingredient (Table 2). The digestibility varied significantly with or without phytase utilization, and was significantly lower when soybean meal was used as test ingredient alone. The availability of phosphorous was also affected by fungal phytase addition (Table 3). A significant effect of phytase supplementation on protein and energy utilization rate was observed by Liebert and Portz (2005), recommending this additive for maximum growth performance for Nile tilapia. Most microbial phytase act efficiently under conditions present in the stomach (acid pH), however, not all phytase have the same pH profile (Morales et al., 2011). In this study, Aspergillus niger phytase showed optimum $\mathrm{pH}$ at 5 . Also, as Nile tilapia stomach $\mathrm{pH}$ is acid, phytase activity increase in low $\mathrm{pH}$ and protein digestion occurs in the stomach; this condition may help to improve protein digestibility.

Vielma et al. (2004) reported positive effects of supplemented phytase on protein digestibility in rainbow trout (Oncorhynchus mykiss); however, protein utilization was not significantly increased. Researchers have shown enhanced amino acid and protein availability due to supplemental phytase for land animals (Sebastian et al., 1997; Martin et al., 1998) and fish (Guimarães et al., 2009). Likewise, plant protein utilization has been reported to increase by enzymes utilization in several studies (Storebakken et al., 1998; Vielma et al., 2004; Sugiura et al., 2001). Hien et al. (2015) showed that the soybean meal supplemented with phytase, lysine, threonine and methionine can substitute fish meal by $40 \%$ for Channa striata and Channa micropeltes fingerlings, without affecting performance, feed efficiency and survival.

As expected, the supplementation effect of microbial phytase and/or protease on phosphorous, magnesium, calcium and manganese utilization was significant when added to soybean meal (Table 3). Apparent phosphorous availability and bone mineralization are considered as the most sensitive conditions for assessing the influence of phytase on phosphorous utilization (Cao et al., 2007). Currently, the capacity of phytase to increase total phosphorous availability in fish has been demonstrated. Sugiura et al. (2001) observed that for rainbow trout fed diet with $50 \%$ soybean meal pretreated with $1000 \mathrm{U}_{\text {phytase }} \mathrm{kg}^{-1}$, the ADC of phosphorous reached 93\%. Sajjadi and Carter (2004) reported that phosphorous availability after phytase supplementation was significant higher for Atlantic salmon (Salmon salar) when compared to control diets without phytase. Additionally, the positive effect of phytase on ADC of phosphorous has also been observed in Nile tilapia fed soybean meal based diets (Liebert and Portz, 2005).

Moreover, the digestibility of energy and lipid where increased with addition of fungal protease to soybean meal (Table 2). The availability of phosphorous also ranged from 36.39 to $82.63 \%$, with no enzyme and protease addition in soybean meal, respectively (Table 3 ). The enzyme activity is linked to the animal feeding habits (Sabapathy and Teo, 1993), this may modify the enzyme addition effect on the ingredient, as it can be more efficient for some fish species than others. Likewise, exogenous protease added to diet of Cichla sp., a carnivorous fish, affected body characteristics and growth performance (Soares et al., 2008), however, these authors did not studied the effect of protease on nutrients digestibility. $\mathrm{Ng}$ et al. (2002) observed reduction of anti-nutrients effect and increase of nutritional value of palm bran for Nile tilapia; and the use of an enzyme complex, including protease, for Nile tilapia diets improved the digestibility of protein, fat and gross energy digestibility (Guimarães et al., 2009). The exogenous protease could be responsible for increase and complement the enzyme-substrate machinery, improving even carbohydrates and lipids digestion. And more, similarly to phytase, protease can degrade some proteins that act as anti-nutritional factors and improve nutrients digestibility.

Otherwise, there were no differences for corn gluten treatments with enzymes addition (Tables 2 and 3). Corn gluten nutritional composition, as amino acids, minerals or other components, may have caused an inhibition on the activity site of the enzyme produced and, for this reason, enzyme addition did not work for this ingredient. Even more, when the enzymes were combined in the treatments, they did not show improvement on ingredients digestibility. This may show that the fungal protease produced can degrade the phytase and increase the negative effect on gluten digestibility and its anti-nutrients. In this sense, the stability of phytase during stomach digestion in the presence of pepsin may be a limiting factor for its efficiency and more studies simulating the fish stomach conditions and interaction with ingredients might be needed. On the other hand, calcium availability improved

Table 3

Phosphorous (P), Magnesium (Mg), Calcium (Ca) and Manganese (Mn) availability of plant based ingredients, soybean meal and corn gluten, and enzymes addition.

\begin{tabular}{|c|c|c|c|c|c|c|c|c|}
\hline \multirow[t]{2}{*}{ Treatment } & \multicolumn{4}{|c|}{ Soybean meal } & \multicolumn{4}{|l|}{ Corn gluten } \\
\hline & No enzyme & Phytase & Protease & Phytase + protease & No enzyme & Phytase & Protease & Phytase + protease \\
\hline Phosphorous & $36.39 \mathrm{c}$ & $80.22 \mathrm{ab}$ & $82.63 \mathrm{a}$ & $75.03 \mathrm{ab}$ & $66.55 \mathrm{abc}$ & $48.08 \mathrm{bc}$ & $54.41 \mathrm{abc}$ & $68.70 \mathrm{abc}$ \\
\hline Magnesium & $66.09 \mathrm{c}$ & $79.45 \mathrm{~b}$ & $78.51 \mathrm{bc}$ & $92.05 \mathrm{a}$ & $73.71 \mathrm{bc}$ & $49.74 \mathrm{~d}$ & $66.22 \mathrm{c}$ & $76.78 \mathrm{bc}$ \\
\hline Calcium & $18.03 \mathrm{~cd}$ & $38.91 \mathrm{bc}$ & $73.28 \mathrm{a}$ & $62.50 \mathrm{ab}$ & $5.29 \mathrm{~d}$ & $15.32 \mathrm{~cd}$ & $56.23 \mathrm{ab}$ & $52.92 \mathrm{ab}$ \\
\hline Manganese & $-281.78 \mathrm{e}$ & $37.17 \mathrm{~d}$ & $70.86 \mathrm{~b}$ & $94.41 \mathrm{a}$ & $47.00 \mathrm{~cd}$ & $46.51 \mathrm{~cd}$ & $65.68 \mathrm{bc}$ & $51.55 \mathrm{bcd}$ \\
\hline
\end{tabular}

Values with different letters within a row indicate significant difference $(P<0.05)$. 
with protease addition in the diet for both plant ingredients. Calcium chemical characteristic may be responsible for that improvement, as it is a metal ion that can also bound to phytate and anti-nutritional factors. Many studies reported increase in protein digestibility with microbial phytase supplementation in plant based diets using soybean bran (Liebert and Portz, 2005; Vielma et al., 2004), on the other hand, corn gluten needs further considerations. Likewise, Gonçalves et al. (2007) identified that phosphorous availability varies according the vegetable ingredient used and defined that mineral availability for corn gluten diets with phytase addition was improved only with high levels of enzyme addition, also due to its natural phytase occurrence or the amount of phytate present in the corn gluten. Furthermore, high levels of plant ingredients in the diet result in high content of insoluble carbohydrates, as well as elevated levels of anti-nutritional ingredients like phytates (Francis et al., 2001; Riche et al., 2001). According to Tacon (1993), oilseed meals contain many thermostable anti-nutrients and most importantly enzyme inhibitors. Whether these or other anti-nutrients factors were totally inactivated was not determined in this study. Also, it is important to remember that the enzymes are substrate specific and the corn gluten has different composition than soybean meal, so this might affect in the nutrients utilization as well.

The lipids digestibility was over estimated when both enzymes were added to the ingredients; this may indicate the presence of other enzymes, like lipases in the fungal enzyme complex produced, since the homemade enzymes were used as a crude extract and they were not purified. Furthermore, because of lipase presence, lipids release in the faeces can be more than what should be expected. Supplementation of phytase may also improve the bioavailability of protein and might lead to additional improvements in growth and energy deposition or lipids excretion. The reduction of phytate-protein complexes in the gut and increased nutrient availability could be an explanation for this observation. In vitro studies of Singh and Krikorian (1982) demonstrated negative effects of phytates on protein utilization.

In addition, the optimum supplemental doses of the enzymes for each ingredient may need further research. Also, the interaction between enzymes and sources need more attention to encounter an ideal way to maximize enzyme efficacy. Further investigations are necessary to clarify the influence of supplemental fungal enzymes on nutrients and minerals utilization in fish. Thereby, this additive may reduce environmental pollution by phosphorous and other minerals excreted, as they increase mineral availability, reducing the mineral input and water pollution.

\section{Conclusion}

In conclusion, the substrate, as well as, the microorganism species can affect the biochemical character of the enzyme produced. Additionally, both microbial enzymes demonstrated to be efficient for increasing nutritional utilization of soybean meal for Nile tilapia; and more, these low cost enzymes are alternative additives to improve soybean meal digestibility for a cost-effective and environmentally friendly fish diet.

\section{Acknowledgements}

This study was supported by São Paulo Research Foundation (FAPESP), process number 2013/02998-9.

\section{References}

AOAC, 1995. Official Methods of Analysis. Association of Official Agricultural Chemists, Washington.

Bremer-Neto, H., Graner, C.A.F., Pezzato, L.E., Padovani, C.R., 2005. The spectrophotometric method on the routine of 1,5-diphenylcarbazide was adjusted on chromium determination in feces, after its utilization as a biological marker as chromium (III) oxide. Cienc. Rural 35, 691-697.

Bureau, D.P., Harris, A.M., Cho, C.Y., 1999. Apparent digestibility of rendered animal protein ingredients for rainbow trout (Oncorhynchus mykiss). Aquaculture 180, 345-358.

Cao, L., Wang, W., Yang, C., Yang, Y., Diana, J., Yakupitiyage, A., Luo, Z., Li, D., 2007. Application of microbial phytase in fish feed. Enzym. Microb. Technol. 40, 497-507.

Charney, J., Tomarelli, R.M., 1947. A colorimetric method for the determination of the proteolytic activity of duodenal juice. J. Biol. Chem. 170 (23), 501-505.

Cheryan, M., 1980. Phytic acid interactions in food systems. Crit. Rev. Food Sci. Nutr. 13, 297-335.

Cho, C.Y., Slinger, S.J., Bayley, H.S., 1982. Bioenergetics of salmonid fishes: energy intake, expenditure and productivity. Comp. Biochem. Physiol. 73 (B), 25-41.

Dalsgaard, J., Ekmann, K.S., Pedersen, P.B., Verlhac, V., 2009. Effect of supplemented fungal phytase on performance and phosphorous availability by phosphorous-depleted juvenile rainbow trout (Oncorhynchus mykiss), and on the magnitude and composition of phosphorous waste output. Aquaculture 286, 105-112.

Denstadli, V., Hillestad, M., Verlhac, V., Klausen, M., Øverland, M., 2011. Enzyme pretreatment of fibrous ingredients for carnivorous fish: effects on nutriente utilisation and technical feed quality in rainbow trout (Oncurhynchus mykiss). Aquaculture 319, 391-397.

Elkhalil, E.A.I., Manner, K., Borriss, R., Simon, O., 2007. In vitro and in vivo characteristics of bacterial phytases and their efficacy in broiler chickens. Br. Poult. Sci. 48, 64-70.

Francis, G., Makkar, H.P.S., Becher, K., 2001. Anti-nutritional factors present in plantderived alternate fish ingredients and their effects in fish. Aquaculture 199, 197-227.

Gonçalves, G.S., et al., 2007. Apparent availability for phosphorous in plant ingredientes and phytase enzyme supplementation for Nile tilapia. Rev. Bras. Zootec. 36, 1473-1480.

Guimarães, I.G., Falcon, D.R., Schich, D., Barros, M.M., Pezzato, L.E., 2009. Apparent digestibility of diets containing enzymes supplement for Nile tilapia. Arq. Bras. Med. Vet. Zootec. 61 (6), 1397-1402.

Hardy, R.W., 2010. Utilization of plant proteins in fish diets: effects of global demand and supplies of fishmeal. Aquac. Res. 41 (5), 770-776.

Hassaan, M.S., Soltan, M.A., Abdel-Moez, A.M., 2015. Nutritive value of soybean meal after solid state fermentation with Saccharomyces Cerevisiae for Nile tilapia, Oreochromis niloticus. Anim. Feed Sci. Technol. 201, 89-98.

Hien, T.T.T., et al., 2015. Development of formulated diets for snakehead (Channa striata and Channa micropeltes): can phytase and taurine supplementation increase use of soybean meal to replace fish meal? Aquaculture 448, 334-340.

Liebert, F., Portz, L., 2005. Nutrient utilization of Nile tilapia Oreochromis niloticus fed plant based low phosphorous diets supplemented with graded levels of different sources of microbial phytase. Aquaculture 248, 111-119.

Mahmoud, M.M.A., Kilany, O.E., Dessouki, A.A., 2014. Effects of fish meal replacement with soybean meal and use of exogenous enzymes in diets of Nile tilapia (Oreochromis niloticus) on growth, feed utilization, histopathological changes and blood parameters. Life Sci. 11 (2), 6-18.

Martin, E.A., Nolan, J.V., Nitsan, Z., Farrell, D.J., 1998. Strategies to improve the nutritive value of rice bran in poultry diets: IV. Effects of addition of fish meal and a microbial phytase to duckling diets on bird performance and amino acid digestibility. Br. Poult. Sci. 39, 612-621.

Moraes, P.M., Loureiro, V.R., Padilha, P.M., 2009. Determinação de fósforo biodisponível em rações de peixes utilizando extração assistida por ultra-som e espectrofotometria no visível. Quim Nova 32 (4), 923-927.

Morales, G.A., Moyano, F.J., Marquez, L., 2011. In vitro assessment of the effects of phytate and phytase on nitrogen and phosphorus bio accessibility within fish digestive tract. Anim. Feed Sci. Technol. 170, 209-221.

$\mathrm{Ng}$, W.K., et al., 2002. Nutritive value of palm kernel meal pretreated with enzyme or fermented with Trichoderma koningii as a dietary ingredient for red hybrid tilapia (Oreochromis sp.). Aquac. Res. 33, 1199-1207.

Novelli, P.K., Barros, M.M., Fleuri, L.F., 2016. Novel inexpensive fungi proteases: production by solid state fermentation and characterization. Food Chem. 198, 119-124. http://dx.doi.org/10.1016/j.foodchem.2015.11.089.

NRC (National Research Council), 2011. Nutrient Requirements of Fish and Shrimp. National Academic Press, Washington, DC, USA (376 pp).

Pezzato, L.E., Barros, M.M., Fracalossi, D.M., Cyrino, J.E.P., 2004. Nutrição de peixes. In: Cyrino, J.E.P., Urbinati, E.C., Fracalossi, D.M., Castagnolli, N. (Eds.), Tópicos Especiais em Piscicultura de água Doce Tropical Intensiva. Aquabil, São Paulo, pp. 75-170.

Portz, L., Liebert, F., 2004. Growth, nutrient utilization and parameters of mineral metabolism in Nile tilapia Oreochromis niloticus (Linnaeus, 1758) fed plant-based diets with graded levels of microbial phytase. J. Anim. Physiol. Anim. Nutr. 88, 311-320.

Riche, M., Trottier, N.L., Ku, P.K., Garling, D.L., 2001. Apparent digestibility of crude protein and apparent availability of individual amino acids in tilapia (Oreochromis niloticus) fed phytase pretreated soybean meal diets. Fish Physiol. Biochem. 25, 181-194. http://dx.doi.org/10.1023/A:1022222431004.

Sabapathy, U., Teo, H., 1993. A quantitative study of some digestive enzymes in the rabbitfish (Siiganus canaliculatus) and the seabass (Lates calcifer). J. Fish Biol. 42 (4), 595-602.

Sajjadi, M., Carter, C.G., 2004. Effect of phytic acid and phytase on feed intake, growth, digestibility and trypsin activity in Atlantic salmon (Salmo salar L.). Aquac. Nutr. 10 (2), 135-142.

Sebastian, S., Touchburn, S.P., Chavez, E.R., Lague, P.C., 1997. Apparent digestibility of protein and amino acids in broiler chickens fed a corn-soybean diet supplemented with microbial phytase. Poult. Sci. 76, 1760-1769.

Singh, M., Krikorian, A.D., 1982. Inhibition of trypsin activity in vitro by phytate. J. Agric. Food Chem. 30, 799-800.

Soares, E.C., Pereira Filho, M., Roubach, R., Silva, R.C.S., 2008. Exogenous protease in diets for tucunaré paca (Cichla sp.) juvenille. Rev. Bras. Zootec. 37 (6), 971-976. 
Stockmann, C., Losen, M., Dahlems, U., Knocke, C., Gellissen, G., Büchs, J., 2003. Effect of oxygen supply on passing, stabilizing and screening of recombinant Hansenula polymorpha production strains in test tubes cultures. FEMS Yeast Res. 4, 195-205.

Storebakken, T., Shearer, K.D., Roem, A.J., 1998. Availability of protein, phosphorus and other elements in fish meal, soy protein concentrate and phytase treated soy protein concentrate based diets to Atlantic salmon (Salmo salar). Aquaculture 161, 365-379.

Sugiura, S.H., Gabaudan, J., Dong, F.M., Hardy, R.W., 2001. Dietary microbial phytase supplementation and the utilization of phosphorous, trace minerals and protein by rainbow trout Oncorhyncus mykiss (Walbaum) fed soybean meal based diets. Aquac Res. 32, 583-589.

Tacon, A.G.J., 1993. Feed formulation and on-farm feed management. In: New, M.B.,
Tacon, A.G.J., Csavas, I. (Eds.), Farm-made Aquafeeds. Proceedings of the FAO/ AADCP Regional Expert Consultation on Farm-Made Aquafeeds. FAO-RAPA/AADCP, Bangkok, pp. 61-74.

Uyar, F., Baysal, Z., 2004. Production and optimization of process parameters for alkaline protease production by a newly isolated Bacillus sp. under solid-state fermentation. Process Biochem. 39, 1893-1898.

Vielma, J., Ruohonen, K., Gabaudan, J., Vogel, K., 2004. A top-spraying soybean mealbased diet with phytase improves protein and mineral digestibility but not lysine utilization in rainbow trout, Oncorhynchus mykiss (Walbaum). Aquac. Res. 35 955-964. 